\title{
PENGARUH MODAL INTELEKUAL TERHADAPPROFITABILITAS, PRODUKTIVITAS, NILAIPASAR PERUSAHAAN DAN PERTUMBUHAN PERUSAHAAN PERBANKAN YANG TERDAFTAR DI BURSA EFEK INDONESIA TAHUN $2014-2017$
}

\author{
Inda Gumilang \\ inda.gumilang2@gmail.com \\ Fakultas Ekonomi dan Bisnis Universitas Banten Jaya
}

Abstract

This study aims to examine the effect of intellectual capital and on profitability, productivity, market value and growth listed on the Indonesia Stock Exchange in 2014-2017. By using the Public Value Added Intellectual Capital (VAIC) model, the study examines the relationship between the efficiency of Value Added Intellectual Capital (VAIC) from the three main sources of Value Added Human Capital (VAHU), Sructural Capital Value Added (SCVA). Profitability is measured using Return On Assets (ROA), Productivity is measured using Asset Turn Over (ATO), Market Value is measured using Price to Book Value (PBV) and Growth is measured using Earning Growth (EG). The research sample used a purposive sampling method. The research design is complex, secondary data types, data sources are obtained from www.idx.co.id, the websites of each Banking and Investment Gallery Indonesia Stock Exchange Untirta Serang. The data analysis technique uses Statistical Package The Social (SPSS). The test results prove that probabilities affect intellectual capital, productivity affects intellectual capital, market value influences intellectual capital and growth influences intellectual capital.

Keywords: intellectual capital, probability, productivity, market value an growth 
JUMANIS - BAJA VOL 4 NO 1 Prodi Kewirausahaan Februari 2022

ISSN : 2686-0554

ESSN : 2686-5939

DOI : $\mathbf{1 0 . 4 7 0 8 0}$

Abstrak

Penelitian ini bertujuan untuk menguji pengaruh modal intelektual dan terhadap profitabilitas, produktivitas, nilai pasar dan pertumbuhan yang terdaftar di Bursa Efek Indonesia tahun 2014-2017. Dengan menggunakan model Public Value Added Intellectual Capital (VAIC), penelitian ini mengkaji hubungan antara efisiensi Value Added Intellectual Capital (VAIC) dari tiga sumber utama Value Added Human Capital (VAHU), Sructural Capital Value Added (SCVA) . Profitabilitas diukur dengan Return On Assets (ROA), Productivity diukur dengan Asset Turn Over (ATO), Market Value diukur dengan Price to Book Value (PBV) dan Pertumbuhan diukur dengan Earning Growth (EG). Sampel penelitian menggunakan metode purposive sampling. Desain penelitian ini kompleks, jenis data sekunder, sumber data diperoleh dari www.idx.co.id, website masing-masing Galeri Perbankan dan Investasi Bursa Efek Indonesia Untirta Serang. Teknik analisis data menggunakan Statistical Package The Social (SPSS). Hasil pengujian membuktikan bahwa probabilitas mempengaruhi modal intelektual, produktivitas mempengaruhi modal intelektual, nilai pasar mempengaruhi modal intelektual dan pertumbuhan mempengaruhi modal intelektual.

Kata kunci: modal intelektual, probabilitas, produktivitas, nilai pasar dan pertumbuhan

A. PENDAHULUAN

Perkembangan dalam bidang ekonomi membawa dampak perubahan yang cukup signifikan terhadap pengelolaan suatu bisnis dan penentuan strategi bersaing. Para pelaku bisnis mulai menyadari bahwa kemampuan bersaing tidak hanya terletak pada kepemilikan aktiva berwujud, tetapi lebih pada inovasi, sistem informasi, pengelolaan organisasi dan sumber daya manusia yang dimilikinya. Oleh karena itu, organisasi bisnis semakin menitik beratkan akan pentingnya knowledge asset (aset pengetahuan) sebagai salah satu bentuk aset tak berwujud (Agnes, 2008). Bahkan Starovic et.al. (2003) menemukan bahwa pengetahuan telah menjadi mesin baru dalam pengembangan suatu bisnis.

Pengetahuan diakui sebagai komponen esensial bisnis dan sumber daya strategis yang lebih sustainable (berkelanjutan) untuk memperoleh dan mempertahankan competitive advantage (Asni, 2007). Bahkan Starovic at.al. (2003), menemukan knowledge asst telah menjadi mesin baru dalam 
JUMANIS - BAJA VOL 4 NO 1 Prodi Kewirausahaan Februari 2022

ISSN : 2686-0554

ESSN : 2686-5939

DOI : $\mathbf{1 0 . 4 7 0 8 0}$

pengembangan suatu bisnis. Perusahaan sebagai salah satu bentuk organisasi pada umumnya memiliki tujua tertentu yang ingin dicapai dalam usaha untuk memenuhi kepentingan para anggotanya dan keberhasilan dalam mencapai tujuan tersebut merupakan prestasi bagi manajemen (Ermayanti, 2009).

Pada sektor perbankan, modal intelektual merupakan salah satu aset yang sangat signifikan. Hal ini sesuai dengan penelitian Firer dan William (2003) yang menyatakan bahwa industri perbankan merupakan salah satu sektor yang paling intensif modal intelektual. Dalam rangka meningkatkan kinerjanya, industri perbankan banyak melakukan berbagai macam pelayanan berbasis teknologi informasi pada para nasabahnya. Terlebih, pada akhir-akhir ini banyak bank yang mulai menerapkan knowledge based business. Menurut Fifer dan Williams (2003), manajemen berbasis pengetahuan telah menjadi terobosan baru bagi organisasi modern yang berharap dapat berkompetisi pada suatu lingkungan dengan tekanan yang terus meningkat.

Pemilihan sektor perbankan sebagai sampel mengacu pada penelitian Firer dan William (2003). Sektor perbankan dipilih karena menurut Firer dan William (2003) industri perbankan adalah salah satu sektor yang paling intensif ICnya. Pertumbuhan bank di Indonesia selalu mengalami gelombang pasang surut yang dilihat dari perkembangan tingkat laba dan aktiva. Gelombang naik turun tersebut relatif teratur dan terjadi berulang- ulang dengan rentang waktu yang bervariasi. Ketidakstabilan ini karena adanya ancaman globalisasi dan pasar bebas di dunia perekonomian internasional. Pangsa kredit perbankan dalam pembiayaan perekonomian mencapai sekitar 48 persen. Oleh karena itu, penting peranan perbankan yang kuat dan sehat bagi kelangsungan pembangunan ekonomi di Indonesia, salah satunya peranan perbankan asing yang ada di Indonesia. Bank memiliki peran yang sangat penting dalam perekonomian.

Perbankan mempunyai pangsa pasar besar sekitar $80 \%$ dari keseluruhan sistem keuangan yang ada. Mengingat begitu besarnya peranan perbankan dalam pembiayaan perekonomian sangat dominan di Indonesia. Maka pengambil keputusan perlu melakukan evaluasi kinerja yang memadai. Rasio pertumbuhan merupakan indikator yang paling tepat untuk mengukur peningkatan aktivitas perusahaan dalam jangka panjang. Selain itu, dari aspek intelektual, secara 
JUMANIS - BAJA VOL 4 NO 1 Prodi Kewirausahaan Februari 2022

ISSN : 2686-0554

ESSN : 2686-5939

DOI : 10.47080

keseluruhan karyawan di sektor perbankan lebih homogen dibandingkan dengan sektor ekonomi lainnya (Kubo dan Saka, 2002).

Menurut Dendawijaya (2003:126) hal tersebut dikarenakan sektor perbankan menandalkan kepercayaan dalam mengeloa dana, baik dana pemilik maupu dana masyarakat. Perbankan diharapkan dapat memperoleh modal intelektual yang kuat dalam mengantisipasi persainagan masa depan melalui sumber daya manusia yang unggul, kratif dan memiliki visi jauh ke depan.

Modal intelektual merupakan materi intlektual yang telah diformalisasikan, ditangkap dan diungkit untuk menciptakan kekayaan dengan menghasilkan suatu aset yang bernilai tinggi (Ulum, 2009:19). Modal intelektual memang masih baru dan belum banyak ditanggapi oleh para pelaku bisnis global, padahal adanya perbedaan antara nilai buku dengan nilai pasar saham (perbedaan ini mencolok untuk perusahaan yang berbasis pengetahuan), menunjukan adanya missing value berupa modal intelektual. Kondisi demikian mengisyaratkan pentingnya dilakukan penilaian terhadap aktiva tak berwujud (Ambar, 2004).

Menurut Sullivan dalam Sangkala (2006) modal intelektual adalah pengetahuan yang dapat diubah menjadi profit. Modal intelektual tidak hanya menyangkut pengetahuan dan keterampilan dari para karyawan, melainkan juga termasuk infrastruktur perusahaan, relasi dengan pelanggan, sistem informasi, teknologi, kemampuan berinovasi, dan berkreasi. Modal intelektual mulai menarik perhatian untuk diteliti ketika terdapat selisih yang meningkat antara nilaipasar dan nilai buku pada banyak perusahaan, selisih nilai pasar dengan nilai bukutersebut merupakan suatu hidden value perusahaan, dan hidden value tersebut merupakan hasil dari modal intelektual yang dimiliki perusahaan.Pengakuan modal intelektual dalam mendorong peningkatkan kinerja keuangan perusahaan dan keunggulan kompettitif, bertolak belakang dengan pengukuran yang tepat terhadap modal intelektual perusahaan belum dapat di tetapkan. Ulum (2008) melakukan pengukuran tidak langsung terhadap modal intelektual perusahaan dengan mengajukan suatu ukuran untuk menilai efisiensi dari nilai tambah sebagai hasil dari kemampuan intelektual perusahaan (value added intellectual capital-VAIC). Komponen untama dari VAIC dapat dilihat dari sumber daya perusahaan, yaitu physcal capital (Value added capital employed-VACA), human 
JUMANIS - BAJA VOL 4 NO 1 Prodi Kewirausahaan Februari 2022

ISSN : 2686-0554

ESSN : 2686-5939

DOI : $\mathbf{1 0 . 4 7 0 8 0}$

capital (Value added human capital-VAHU), dan structural capital (structural capital value added- STVA).

Fenomena modal intelektual di Indonesia mulai berkembang setelah munculnya PSAK No. 19 (revisi 2009) tentang aset tidak berwujud. Modal intelektual mulai mendapat perhatian meskipun tidak dijelaskan secara eksplisit. Menurut PSAK No. 19, aktiva tidak berwujud adalah aktiva non moneter yang dapat diidentifikasi dan tidak mempunyai wujud fisik serta untuk digunakan dalam menghasilkan atau menyerahkan barang atau jasa, disewakan kepada pihak yang lain, atau untuk tujuan administrative (IAI, 2009).

Modal intelektual terus berkembang di Indonesia karena merupakan suatu komponen penting perusahaan dalam penciptaan value added perusahaan. Value added merupakan suatu indikator pertumbuhan dan keberhasilan bisnis (Pulic,1998). Penciptaan nilai adalah ketika perusahan mampu memanfaatkan sumber daya strategis yang dimiliki untuk menciptakan value added bagi perusahaan. Sumber daya strategis dapat berupa sumberdaya berwujud maupun tidak berwujud. Dalam perusahaan berbasis pengetahuan, komponen terpenting dalam penciptaan valueadded bagi perusahaan bukanlah aset berwujud melainkan aset tidak berwujud yaitu modal intelektual. Modal-modal intelektual seperti human capital, structuralcapital, dan relational capital merupakan suatu komponen penting perusahaan dalam penciptaan value added perusahaan. Human capital meliputi keahlian, pengetahuan, motivasi, integritas yang dimiliki karyawan. Sedangkan structural capital merupakan budaya organisasi yang dibangun oleh perusahaan dan relational capital meliputi loyalitas konsumen, hubungan terhadap pemasok, pelayanan terhadap konsumen.

Di IndonesiaUlum (2007) telah melakukan pengujian terhadap hubungan modal intelektual dan kinerja keuangan perusahaan sektor perbankan. Hasilnya menunjukan berpengaruh terhadap kinerja keuangan perusahaan.

Profitabilitas mengukur efektifitas manajemen berdasarkan hasil pengembalian yang dihasilkan dari pinjaman dan investasi. Indikator yang biasa digunakan utnuk mengukur kinerja profitabilitas bank adalah ROA (Return on Assets) yaitu rasio yang 
JUMANIS - BAJA VOL 4 NO 1 Prodi Kewirausahaan Februari 2022

ISSN : 2686-0554

ESSN : 2686-5939

DOI : $\mathbf{1 0 . 4 7 0 8 0}$

menunjukkan kemampuan dari keseluruhan aktiva yang ada dan yang digunakan untuk menghasilkan keuntungan.

Menanggapi hal tersebut, Direktur Utama PT Bank Mandiri (Persero) Tbk Kartika Wirjoatmodjo menilai, tahun ini ROA masih akan berada di level yang stabil. Menurutnya, sampai akhir 2018 ROA Bank Mandiri akan berada di kisaran 2,5\%. Sebagai contoh perkembangan ROA pada Bank Mandiri pada akhir tahun 2017 lalu yang sempat mencapai 2,72\%,. ROA Bank Mandiri tahun 2017 pun naik cukup tinggi, bila dibandingkan periode tahun 2016 yang hanya $1,95 \%$.

Kelebihan metode yang dikembangkan oleh Pulic adalah data-data yang dibutuhkan untuk mengukur modal intelektual relatif mudah diperoleh dari berbagai sumber dan jenis perusahaan. Data yang dibutuhkan untuk menghitung berbagai rasio tersebut merupakan angka- angka standar yang pada umumnya tersedia dalam laporan keuangan perusahaan.

Penyusunan laporan keuangan ini menjadi bukti bahwa dana yang dikeluarkan oleh pemegang saham telah digunakan secara efektif dan efisien untuk membiayai operasional perusahaan sehingga nantinya akan memberikan keuntungan bagi pemegang saham atas uang yang teleh mereka investasikan ke perusahaan tersebut. Bukan hanya hal itu adanya standar pelaporan yang semakin berkualitas, juga keinginan perusahaan untuk menerbitkan laporan keuangan yang bagus agar dapat menarik investor telah mendorong perusahaan untuk menampilkan informasi yang lebih luas, berkualitas dan real time. Dalam bisnis yang berbasis pengetahuan ini keberadaan modal yang bersifat pengetahuan dan teknologi jauh lebih penting dibandingkan modal yang bersifat konvensional seperti sumberdaya keuangan maupun sumberdaya alam. Rupert (dalam Sawarjuwono dan Kadir 2003) menyatakan bahwa "karena menggunakan ilmu pengetahuan dan teknologi, maka akan diperoleh metode penggunaan sumberdaya lainnya secara efisien dan ekonomis, yang nantinya akan memberikan keunggulan kompetitif".

Zhang et, al (2006) dalam peneltian Tiongkok. Gosh dan Mondal (2009) menyatakan bahwa modal intelektual juga berpengaruh pada tingkat profitabilitas perusahaan sektor perangkat lunak komputer dan farmasi di India. Namun demikian Firer dan Williams (2003) melakukan penelitian pada 75 perusahaan publik di Afrika Selatan menemukan bahwa modal intelktual dan kinerja keuangan tidak memiliki signifikan. Nijbullah (2005) yang meniliti modal intelektual dengan kinerja pada perusahaan sektor 
JUMANIS - BAJA VOL 4 NO 1 Prodi Kewirausahaan Februari 2022

ISSN : 2686-0554

ESSN : 2686-5939

DOI : 10.47080

perbankan yang listing di Dhaka Stock Exchange-Bangladesh juga memiliki tidak ada hubungan antara modal intelektual dengan kinerja perusahaan dan market value perusahaan.

Kinerja perusahaan selain dapat dilihat dari profitabilitas juga tercermin dari produktivitasnya. Informasi tentang produktivitas perusahaan tercermin dalam laporan keuangan yang disajikan setiap tahunnya. Sering kali penurunan produktivitas kerja terjadi pada suatu perusahaan karena karyawan tidak mampu mengikuti standar produktivitas yang diinginkan oleh pimpinan. Oleh karena itu suatu mekanisme atau cara dibutuhkan agar produktivitas kerja bisa dicapai dan dilaksanakan oleh seluruh karyawan dan divisi perusahaan. Salah satu cara yang dapat dilakukan untuk meningkatkan produktivitas perusahaan adalah dengan efisiensi.

Nilai perusahaan merupakan konsep penting bagi para investor, karena merupakan indikator bagi pasar untuk menilai sebuah perusahaan secara keseluruhan (Mahendra, dkk, 2012). Menurut Putu, dkk (2014), nilai perusahaan adalah persepsi investor terhadap perusahaan yang sering dikaitkan dengan harga saham. Tujuan utamanya adalah memaksimalkan kekayaan perusahaan atau nilai perusahaan. Memaksimalkan nilai perusahaan sangat Menurut Ulum (2008) perusahaan yang mampu mengelola sumber daya intelektualnya dengan efisien akan menciptakan value added dan competitiveadvantage yang akan bermuara pada peningkatan kinerja keuangan perusahaan penting, hal tersebut berarti sekaligus memaksimalkan kekayaan pemegang saham sebagai tujuan utama perusahaan.

Semakin tinggi harga saham perusahaan tersebut, maka nilai perusahaan juga semakin tinggi, demikian pula dengan kekayaan para pemegang sahamnya (Febrianti, 2012). Pada dasarnya harga saham dipengaruhi oleh profitabilitas di masa yang akan datang dan resiko yang ditanggung oleh pemodal. Harga saham yang tinggi membuat nilai perusahaan juga tinggi. Nilai perusahaan yang tinggi akan membuat pasar tidak hanya percaya pada kinerja perusahaan saat ini namun juga pada prospek masa depan perusahaan (Ali dan Maryam, 2015).

Untuk menilai suatu perusahaan dari harga pasar saham, biasanya digunakan pengukuran kinerja perusahaan. Semakin baik kinerja perusahaan, maka semakin tinggi return yang akan diperoleh oleh investor (Meythi, 2013). Bagi sebuah perusahaan, menjaga dan meningkatkan kinerja perusahaan adalah suatu keharusan 
agar saham perusahaan tersebut tetap eksis dan tetap diminati oleh para investor (Mahendra, dkk, 2012). Meningkatnya gap yang diamati antara nilai pasar dan nilai buku dari banyak perusahaan telah menarik perhatian untuk meneliti nilai yang hilang dari laporan keuangan. berbagai peneliti menyatakan bahwa, modal intelektual dianggap sebagai nilai tersembunyi yang tidak tercatat dalam laporan keuangan dan salah satu hal yang mampu mendorong perusahaan untuk memperoleh keunggulan kompetitif. (Chen et al, 2005;. Edvinsson dan Malone, 1997; Lev dan Radhakrishnan, 2003;Lev dan Zarowin, 1999; Lev, 2001; Ruta, 2009; Yang dan Lin, 2009).

Menurut Yuniarsih dan Suwatno (2008:156) bahwa produktivitas kerja karyawan adalah hasil konkrit (produk) yang dihasilkan oleh individu atau kelompok, selama satuan waktu tertentu dalam suatu proses kerja. Menurut Greeberg yang dikutip oleh Yuniarsih dan Suwatno (2008:157) mendefinisikan produktivitas sebagai perbandingan antar totalitas pengeluaran pada waktu tertentu dibagi totalitas masukan selama periode tersebut. Produktivitas berpengaruh terhadap modal intelektual, pernyataan tersebut didukung oleh teori Sawarjono dan Kadir yang menyatakan bahwa "Dimana produktivitas juga dapat memberikan informasi tentang meningkat dan menurunnya modal intelektual.

Berdasarkan beberapa penelitian mengenai pengaruh modal intelektual terhadap profitabilitas, produktifitas, nilai pasar dan pertumbuhan yang telah dilakukan ternyata masih menunujukkan hasil yang berbeda-beda. Perbedaan perkembangan dan penggunaan teknologi mungkin dapat mengakibatkan perbedaan dalam penggunaan modal intelektual di berbagai negara. Tingkat penggunaan modal intelekrual yang berbeda menyebabkan terjadinya perbedaan kinerja perusahaan dan kemampuan perusahaan dalam menciptakan nilai tambah. Hasil penelitian yang beragam dan seringkali kontradiktif mengenai modal intelektual menunjukkan bahwa masih terjadi research gap dalam penelitian modal intelektual. Adanya perbedaan dari hasil penelitian-penelitian yang dilakukan oleh peneliti sebelumnya membuat penelitian mengenai hubungan modal intelektual terhadap profitabilitas, produktifitas dan penilaian pasar masih menarik untuk diteliti. Hal ini juga didukung dengan semakin vitalnya peranan modal intelektual bagi perusahaan modern karena sifat dari modal intelektual yang sulit ditiru dan tak 
JUMANIS - BAJA VOL 4 NO 1 Prodi Kewirausahaan Februari 2022

ISSN : 2686-0554

ESSN : 2686-5939

DOI : $\mathbf{1 0 . 4 7 0 8 0}$

tergantikan sehingga dapat menciptakan keunggulan kompetitif dan kinerja yang lebih baik.

ROA adalah suatu rasio yang digunakan untuk mengukur tingkat pengembalian atas total aktiva setelah bunga dan pajak. Dengan mengukur ROA akan dapat diketahui efektivitas perusahaan dalam menghasilkan keuntungan dengan menggunakan aktiva yang dimilikinya.Return on assets (ROA) merupakan rasio profitabilitas yang mengukur jumlah laba yang diperoleh dari tiap rupiah aset yang dimiliki oleh perusahaan. ROA menunjukkan kemampuan manajemen bank dalam melakukan efisiensi penggunaan total aset untuk operasional perusahaan. Semakin tinggi ROA suatu bank semakin tinggi pula keuntungan yang dicapai bank tersebut dan semakin baik posisi perusahaan dari segi penggunaan aset. ROA juga memberikan gambaran tentang bagaimana perusahaan mengkonversikan dana yang telah diinvestasikan menjadi laba bersih kepada para investor.

Modal Intelektual merupakan bagian dari pengetahuan yang dapat bermanfaat bagi perusahaan perbankan yaitu mampu memberikan nilai tambah (value added). Nilai tambah tersebut memberikan keunggulan kompetitif bagi perusahaan perbankan sehingga berbeda antara perusahaan satu dengan yang lain.

Modal Intelektual yang bersumber dari kompetensi karyawan, struktur organisasi dan performa yang dimiliki oleh perusahaan perbankan memberikan kemampuan bagi perusahaan untuk melakukan efisiensi biaya yang dapat meningkatkan kinerja keuangan perusahaan. Semakin efisien perusahaan dalam menggunakan asetnya untuk kegiatan operasi maka indikator nilai ROA akan naik. Dengan pemanfaatan sumber daya modal intelektual yang baik dan benar, maka diyakini akan dapat meningkatkan return on assets perusahaan perbankan naik. Dengan pemanfaatan sumber daya Modal Intelektual yang baik dan benar, maka diyakini akan dapat meningkatkan return on assets perusahaan perbankan.

Profitabilitas perusahaan sering diukur dengan return on assets (ROA) yang menunjukkan kemampuan manajemen perusahaan dalam melakukan efisiensi penggunaan total aset untuk operasional perusahaan. Semakin tinggi ROA suatu perusahaan, menunjukkan bahwa semakin tinggi pula keuntungan yang dicapai perusahaan tersebut dan semakin baik posisi perusahaan dari segi penggunaan asset yang dimilikinya. ROA juga memberikan gambaran tentang bagaimana perusahaan 
JUMANIS - BAJA VOL 4 NO 1 Prodi Kewirausahaan Februari 2022

ISSN : 2686-0554

ESSN : 2686-5939

DOI : $\mathbf{1 0 . 4 7 0 8 0}$

mengkonversikan dana yang telah diinvestasikan menjadi laba bersih (Marfuah dan Maricha Ulfa, 2014)

Berdasarkan teori tersebut, dapatdisimpulkan dirumuskan hipotesis sebagai berikut:

\section{H1 : Modal intelektual berpengaruh terhadap profitabilitas}

Produktivitas adalah ukuran ekonomis dari output per unit input sedangkan output dikurangai dengan input adalah nilai tambah (value added). Jadi, employeeproductivity (EP) dapat didefinisikan sebagai ukuran dari nilai tambah bersih per karyawan yang merefleksikan produktivitas karyawan.

Apabila produktivitas karyawan meningkat, maka dapat menurunkan biaya produksi. Jika biaya produksi dapat ditekan, maka harga produk yang dihasilkan dapat turun dan juga dapat meningkatkan kapasitas produksi. Hal ini tentu saja dapat menciptakan keunggulan kompetitif sehingga dapat meningkatkan kemampuan perusahaan dalam bersaing di lingkungan bisnis.

Pengukuran produktivitas yang hanya memperhitungkan salah satu sumber daya sebagai variabel input dikenal sebagai produktifitas faktor tunggal (singlefactor productivity). Sementara pengukuran produktivitas yang memperhitungkan semua variabel input (tenaga kerja, material, energi, modal) dikenal sebagai produktivitas multifaktor (multyfactor productivity) atau produktivitas faktor total (Hayzer dan Render, 2005).

Perhitungan produktivitas membantu manajer perusahaan menilai seberapa baik mereka bekerja. Ukuran produktivitas multifaktor menyajikan infomasi yang lebih baik dalam perhitungan antar faktor, tetapi terdapat beberapa masalah dalam perhitungan tersebut, yaitu (Hayzer dan Render, 2005):

Kualitas dapat berubah walaupun input dan output tetap. Produktivitas faktor adalah kunci untuk menetapkan kombinasi, atau proporsi input (variable proportion) yang optimal yang harus dipergunakan untuk menghasilkan satu produk yang mengacu pada the law of variable proportion. Produktivitas faktor memberikan dasar untuk penggunaan sumber daya yang efisien dalam sebuah sistem produksi. Pengembangan output di mana terdapat sekurangkurangnya satu faktor produksi yang konstan dijelaskan oleh the law of deminishing returns dari faktor berubah. The law of deminishing returns 
JUMANIS - BAJA VOL 4 NO 1 Prodi Kewirausahaan Februari 2022

ISSN : 2686-0554

ESSN : 2686-5939

DOI : $\mathbf{1 0 . 4 7 0 8 0}$

menyatakan bahwa sementara jumlah satu input variabel meningkat, dengan jumlah semua faktor lainnya dinyatakan konstan, kenaikan yang dihasilkan dalam output pada akhirnya akan menurun (Pappas dan Hirschey, 1993 dan Soekartawi, dkk, 1986).

Pada hakekatnya produktivitas kerja akan banyak dipengaruhi oleh dua faktor (Wignjosoebroto, 2003):

Hal ini menunjukkan bahwa perusahaan telah mampu memanfaatkan modal intelektual dengan baik untuk menghasilkan keunggulan dibanding perusahaan lain dan secara langsung mampu meningkatkan produktifitas perusahaan. Ini berarti perusahaan mampu untuk memenuhi proses rutinitas perusahaan dan strukturnya yang mendukung usaha karyawan untuk menghasilkan kinerja bisnis secara keseluruhan, misalnya sistem operasional perusahaan, proses manufakturing, dan semua bentuk properti intelektual yang dimiliki perusahaan.

Dalam penelitian ini terbukti bahwa modal intelektual memiliki pengaruh signifikan terhadap produktivitas perusahaan. Semakin besar jumlah modal intelektual yang dimiliki perusahaan maka semakin baik produktivitas dari perusahaan tersebut (Alwin Agusta, 2017).

Berdasarkan teori tersebut, dapat disimpulkan dirumuskan hipotesis sebagai berikut:

\section{H2: Modal intelektual berpengaruh terhadap produktifitas}

Menurut resource based theory bahwa ukuran efisiensi value added dapat digunakan untuk memprediksi ukuran keuangan secara tradisional. Investor dapat menganalisis value added dan return yang diperoleh perusahaan atas dimanfaatkannya modal intelektual dalam kegiatan operasi perusahaan. Jika modal intelektual dapat memberi gambaran kepada investor mengenai prospek kinerja yang baik di masa yang akan datang, hal tersebut akan meningkatkan permintaan saham perusahaan sehingga harga saham dan kinerja pasar juga akan ikut meningkat. Pemanfaatan modal intelektual secara efektif dan efisien akan berkontribusi signifikan terhadap pencapaian keunggulan kompetitif dan selanjutnya akan tercermin dalam nilai perusahaan yang tinggi. 
JUMANIS - BAJA VOL 4 NO 1 Prodi Kewirausahaan Februari 2022

ISSN : 2686-0554

ESSN : 2686-5939

DOI : $\mathbf{1 0 . 4 7 0 8 0}$

Penelitian yang dilakukan Fransiskus Randa Dan S. Ariyanto Solon (2012) pengaruh modal intelektual terhadap nilai perusahaan menemukan bahwa modal intelektual berpengaruh positif signifikan terhadap nilai perusahaan.

Dalam usaha penciptaan nilai (value creation) diperlukan pemanfaatan seluruh potensi sumber daya yang dimiliki perusahaan. Potensi tersebut meliputi: karyawan (human capital), aset fisik (physical capital) dan structural capital. Value added yang dihasilkan dari proses value creation akan menciptakan keunggulan kompetitif bagi perusahaan. Dengan memiliki keunggulan kompetitif, maka persepsi pasar terhadap nilai perusahaan akan meningkat karena diyakini bahwa perusahaan yang memiliki keunggulan kompetitif mampu bersaing dan bertahan di lingkungan bisnis yang dinamis.

Hasil penelitian memberikan bukti empiris bahwa modal intelektual berpengaruh signifikan terhadap penilaian pasar (Faisal Saleh, 2014).

Penelitian yang dilakukan Faza (2014) menyimpulka bahwa modal intelektual mempunyai pengaruh signifikan terhadap ATO perusahaan.

Berdasarkan teori tersebut, dapat disimpulkan dirumuskan hipotesis sebagai berikut:

\section{H3 : Modal intelektual berpengaruh terhadap nilai pasar}

Pertumbuhan pendapatan yang konsisten, dan juga pertumbuhan keuntungan dianggap penting bagi perusahaan yang dijual ke publik melalui saham untuk menarik investor. Modal intelektual dapat dihubungkan dengan strategi perusahaan yang mencakup inovasi serta strategi pemasaran yang dilakukan oleh perusahaan. Strategi tersebut antara lain dilakukan dengan menyajikan produkproduk yang menarik serta kompetitif dan dapat memberikan kemudahan transaksi bagi nasabah. Dengan demikian semakin besar modal intelektual yang dimiliki perusahaan maka semakin besar pula kemampuan perusahaan untuk meningkatkan pertumbuhan pendapatan (growth in revenue).

Berdasarkan hasil penelitian Solikhah (2010) modal intelektual berpengaruh positif terhadap pertumbuhan perusahaan.

Menurut Marfuah (2014), hasil penelitian memberikan bukti empiris bahwa modal intelektual(Capital employed, physical capital(ekuitas dan laba bersih) terbukti berpengaruh terhadap pertumbuhan perusahaan. 
JUMANIS - BAJA VOL 4 NO 1 Prodi Kewirausahaan Februari 2022

ISSN : 2686-0554

ESSN : 2686-5939

DOI : $\mathbf{1 0 . 4 7 0 8 0}$

Berdasarkan teori tersebut, dapat disimpulkan dirumuskan hipotesis sebagai berikut:

\section{H4 : Modal intelektual berpengaruh terhadap pertumbuhan}

\section{B. METODOLOGI PENELITIAN}

Penelitian ini dilakukan pada perusahaan perbankan yang terdaftar di Bursa Efek Indonesia. Pengamatan dilakukan selama 3 tahun yaitu tahun 2014 dan 2016.

Populasi dalam penelitian ini adalah seluruh perusahaan perbankan yang terdaftar pada Bursa Efek Indonesia. Berikut ini disajikan daftar perusahaan perbankan di Indonesia yang telah listing di Bursa Efek Indonesia (BEI) pada tahun 2014-2016. Teknik pengumpulan data yang digunakan dalam penelitian ini adalah telaah dokumentasi. Telaah dokumentasi adalah metode pengumpulan data dengan mengumpulkan data.Populasi yang digunakan dalam penelitian ini adalah semua yang terdaftar di Bursa Efek Indonesia. Metode pemilihan sampel dalam penelitian ini adalah purposive sampling. Metode purposive sampling akan membatasi sampel yang akan dipilih berdasarkan kriteria tertentu.

Kriteria-kriteria yang ditetapkan dalam pengambilan sampel perusahaan perbankan adalah sebagai berikut:

1. Perusahaan Perbankan yang terdaftar di Bursa Efek Indonesia periode tahun 2014-2016.

2. Perusahaan yang aktif dalam perhitungan saham di Bursa Efek Indonesia selama periode pengamatan dari tahun 2014-2016.

3. Perusahaan Perbankan yang tidak mengalami rugi selama periode pengamatan dari tahun 2014-2016.

4. Perusahaan Perbankan memiliki data-data lengkap untuk data variabel selama periode tahun 2014-2017.

Variabel independen dalam penelitian iniadalah Intellectual Capital, yang diukur berdasarkanvalue added yang diciptakan oleh capital employed(VACA), human capital (VAHU), dan structuralcapital (STVA). Hasil penjumlahan ketiga valueadded tersebut diistilahkan dengan VAIC. 
JUMANIS - BAJA VOL 4 NO 1 Prodi Kewirausahaan Februari 2022

ISSN : 2686-0554

ESSN : 2686-5939

DOI : $\mathbf{1 0 . 4 7 0 8 0}$

Tahapan perhitungan VAIC dapat diuraikansebagai berikut (Ulum, 2009):

1. Menentukan nilai value added (VA) yang dapat dihitung dengan mencari selisih antara output dan input.

$$
\mathrm{VA}=\mathrm{OUT}-\mathrm{IN}
$$

Dimana:

OUT = Output: Jumlah seluruh pendapatan usaha yang dimiliki perusahaan.

IN = Input: Seluruh beban usaha perusahaan kecuali beban karyawan.

2. Menentukan nilai Value Added CapitalEmployed (VACA) yang merupakan indikator VAyang dihasilkan oleh physical capital.

$$
\mathrm{VACA}=\mathrm{VA} / \mathrm{CE}
$$

Dimana:

$\mathrm{VACA}=$ Value Added Capital Employed: rasio dari

VA terhadap CE VA =

Value Added

$\mathrm{CE}=$ Capital Employed: Jumlah total aset yang dimiliki perusahaan

3. Menghitung Value Added Human Capital(VAHU) yang merupakan indikator VA yangdihasilkan oleh human capital

$$
\mathrm{VAHU}=\mathrm{VA} / \mathrm{HC}
$$

Dimana:

VAHU = Value Added Human Capital: merupakanrasio VA terhadap HC VA

= Value Added

$\mathrm{HC}=$ Human Capital $:$ beban gaji karyawan 
JUMANIS - BAJA VOL 4 NO 1 Prodi Kewirausahaan Februari 2022

ISSN : 2686-0554

ESSN : 2686-5939

DOI : $\mathbf{1 0 . 4 7 0 8 0}$

4. Menghitung nilai Structural Capital ValueAdded (STVA) yang merupakan indikator VA yangdihasilkan oleh structural capital perusahaan.

$$
\text { STVA }=\text { SC/VA }
$$

Dimana:

STVA = Structural Capital Value Added : rasio SC

terhadap VA

$\mathrm{SC}=$ Structural Capital: VA-HC

$\mathrm{VA}=$ Value Added

5. Menghitung nilai Value Added IntellectualCoefficient (VAIC) yang merupakan indikator VAyang dihasilkan atas pengelolaan IC perusahaan.

$$
\mathrm{VAIC}=\mathrm{VACA}+\mathrm{VAHU}+\mathrm{STVA}
$$

Variabel dependen dalam penelitian ini yaitu profitabilitas yang diukur dengan ROA(Suhendah, 2012), produktivitas yang diukur dengan ATO dan penilaian pasar yang diukur dengan rasio MB (Firer dan Williams, 2003).

Rasio profitabilitas perusahaan adalah rasio yang diukur berdasarkan perbandingan antara laba setelah pajak dengan total asset perusahaan:

$$
\text { ROA }=\underline{\text { Laba bersih }}
$$

Total Asset

Rasio ini menggambarkan dana yang tertanam pada aktiva berputar dalam satu periode tertentu atau kemampuan modal yang ditanamkan dalam seluruh aktiva untuk menghasilkan pendapatan :

$$
\mathrm{ATO}=\frac{\text { Total Pendapatan }}{\text { Total Aset }}
$$


JUMANIS - BAJA VOL 4 NO 1 Prodi Kewirausahaan Februari 2022

ISSN : 2686-0554

ESSN : 2686-5939

DOI : $\mathbf{1 0 . 4 7 0 8 0}$

Nilai Pasar Perusahaan adalah nilai perusahaan dapat dilihat dari perbandingan antara harga pasar per lembar saham dengan nilai buku perlembar saham

Ket : PBV= $\underline{\text { Price }}$

Book Value per

share 
JUMANIS - BAJA VOL 4 NO 1 Prodi Kewirausahaan Februari 2022

ISSN : 2686-0554

ESSN : 2686-5939

DOI : $\mathbf{1 0 . 4 7 0 8 0}$

Price : adalah harga saham per lembar

Book Value per Share : adalah nilai equitas perusahaan di bagi jumlah saham yang beredar

Pertumbuhan Perusahaan adalah rasio mengambarkan pertumbuhan perusahaan

$$
\mathrm{EG}=\underline{\text { Laba tahun } \mathrm{t}}
$$

Laba tahun t-1-1 x 100.

\section{Metode Analisis}

\section{Analisis Deskriftif}

Analisis data yang dilakukan meliputi statistik deskriptif yang memberikan gambaran atau deskripsi suatu data yang dilihat dari nilai minimum, maksimum, mean, dan deviasi standar dari ketiga variabel yang digunakan dalam penelitian ini.

\section{Uji Asumsi Klasik}

Sebelum dilakukan analisis regresi,terlebih dahulu dilakukan uji asumsi klasik menggunakan tiga uji asumsi klasik yaitu uji normalitas, uji heteroskedastisitas, dan uji autokorelasi. Pengujian normalitas dilakukan dengan uji statistik nonparametrik Kolmogorov-Smirnov (K-S).

Sehubungan dengan penggunaan data sekunder dalam penelitian ini, maka untuk mendapatkan ketepatan model yang akan dianalisis perlu dilakukan pengujian atas beberapa persyaratan asumsi klasik yang mendasari model regresi. Tahapan analisis awal untuk menguji model yang digunakan dalam penelitian ini meliputi langkahlangkah sebagai berikut :

\section{Metode Analisis}

\section{Analisis Deskriftif}

Analisis data yang dilakukan meliputi statistik deskriptif yang memberikan gambaran atau deskripsi suatu data yang dilihat dari nilai minimum, maksimum, 
JUMANIS - BAJA VOL 4 NO 1 Prodi Kewirausahaan Februari 2022

ISSN : 2686-0554

ESSN : 2686-5939

DOI : 10.47080

mean, dan deviasi standar dari ketiga variabel yang digunakan dalam penelitian ini.

\section{Uji Asumsi Klasik}

Sebelum dilakukan analisis regresi,terlebih dahulu dilakukan uji asumsi klasik menggunakan tiga uji asumsi klasik yaitu uji normalitas, uji heteroskedastisitas, dan uji autokorelasi. Pengujian normalitas dilakukan dengan uji statistik nonparametrik Kolmogorov-Smirnov (K-S).

Sehubungan dengan penggunaan data sekunder dalam penelitian ini, maka untuk mendapatkan ketepatan model yang akan dianalisis perlu dilakukan pengujian atas beberapa persyaratan asumsi klasik yang mendasari model regresi. Tahapan analisis awal untuk menguji model yang digunakan dalam penelitian ini meliputi langkahlangkah sebagai berikut :

\section{Uji Normalitas}

Untuk menguji normalitas data dalam penelitian ini digunakan uji statistik Kolmogorov Smirnov (K-S) yang dilakukan dengan membuat hipotesis nol (H0) untuk data berdistribusi normal dan hipotesis alternatif (HA) untuk data tidak berdistribusi normal.

\section{HASIL DAN PEMBAHASAN}

Populasi yang digunakan dalam penelitian ini adalah perusahaan yang terdaftar di Bursa Efek Indonesia (BEI) pada tahun 2014-2017. Sampel perusahaan yang berhasil diperoleh da memenuhi kriteria ada sebanyak 23 perbankan dimana penelitian dilakukan selama 4 tahun yaitu 2014-2017, sehingga data yang terkumpul data sebanyak 92. Data penelitian ini diperoleh dari laporan keuangan perbankan yang terdapat di Bursa Efek Indoseia. Fokus penelitian ini adalah unuk mengetahui pengaruh modal intelektual yang dihitung dengan menggunakan model Public dimana modal intelektual mewakili oleh VAIC (Value Added Intellectual Coefficient), yang terbentuk VACA (Value Added Capital Employed), VAHU (Value Added Human Capital), STVA (Structural Value Added) terhadap Profitabilitas yang diwakili Return On Asset (ROA), Produktivitas yang diwakili Asset Turnover (ATO), Nilai Pasar yang diwakili Price to Book Value (PBV) dan Pertumbuhan yang diwakili Earning Growth (EG). 


\section{Tabel 1Tabel Statistik Deskriptif Descriptive Statistics}
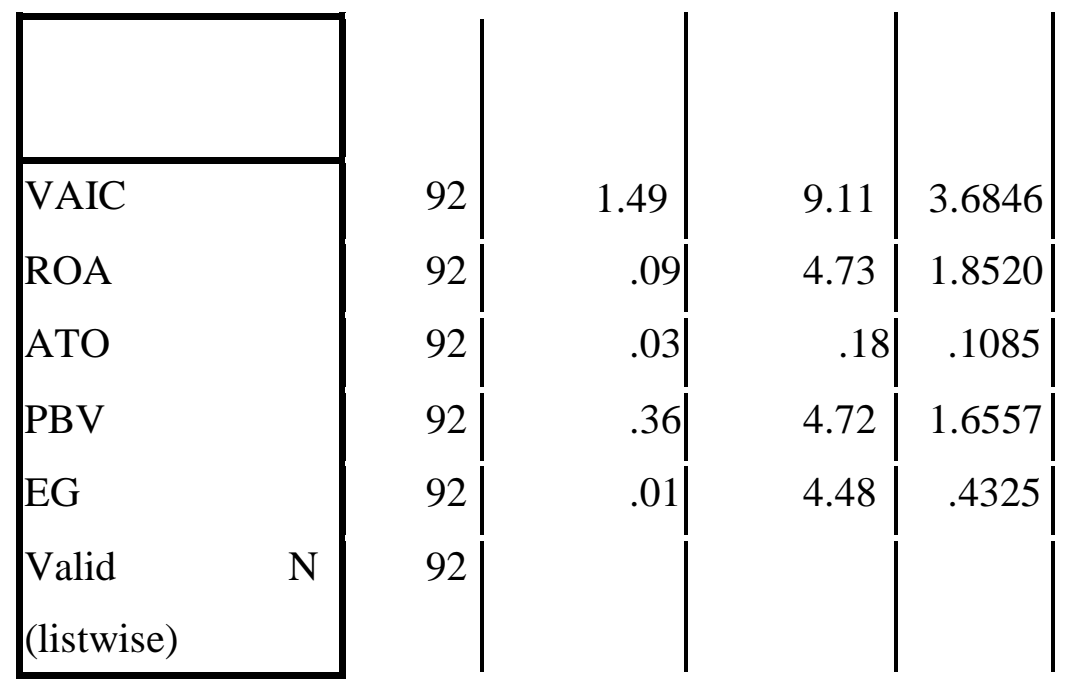

Std.

Deviation

1.61391

.95719

.02572

1.01915

.71525

Sumber: Data sekunder yang diolah dengan SPSS v 17 (2017)

Hasil deskriptif terhadap variabel kinerja keuangan perusahaan perbankan yang diukur dengan ROA menunjukkan hasil yang positif dengan rata-rata 1,8520menunjukkan bahwa perusahaan perbankan telah mampu menghasilkan laba bersih atas pengelolaan seluruh asset yang ada yaitu sebesar $187,8 \%$. Nilai standar deviasi sebesar 0,94747 menunjukkan bahwa penyebaran data Return on Assets memiliki standar deviasi lebih rendah dibandingkan dengan nilai rata-ratanya.

Produktivitas yang diukur ATO, nilai rata-rata sebesar 0,1085 atau $1,35 \%$ dalam setahun menunjukkan bahwa perusahaan perbankan telah mampu yang mengukur kemampuan perusahaan untuk menghasilkan penjualan dari total asetnya dengan membandingkan penjualan bersih dengan total aset rata-rata. Nilai standar deviasi sebesar 0.00733 sehingga menunjukkan bahwa Asset Turnover memilik standar deviasi lebih rendah dibandingkan dengan nilai rata-ratanya.

Nilai pasar yang duikur dengan PBV, nilai rata-rata 1,6557atau sebesar $165,55 \%$ dalam setahun menunjukkan bahwa menunjukkan bahwa perusahaan perbankan membagikan harga per lembar saham perusahaan yang bersangkutan dengan nilai buku per lembar saham (Book Value per Share) dengan rata-rata. Nilai standar deviasi sebesar sebesar 1,01926, sehingga menunjukkan bahwa Price to 
JUMANIS - BAJA VOL 4 NO 1 Prodi Kewirausahaan Februari 2022

ISSN : 2686-0554

ESSN : 2686-5939

DOI : $\mathbf{1 0 . 4 7 0 8 0}$

Book Value memilik standar deviasi lebih rendah dibandingkan dengan nilai rataratanya.

Pertumbuhan yang diukur EG, nilai rata-rata 0,4325atau sebesar 18,8\% dalam setahun menunjukkan bahwa menunjukkan bahwa perusahaan perbankan telah mampu melakukan pertumbuhan laba. Nilai standar deviasi sebesar sebesar 0,67444 sehingga menunjukkan Earming Growth memiliki standar deviasi lebih tinggi dibandingakan dengan nilai rata- ratanya.

Deskripsi data variabel modal inetelektual yang diukur dengan VAIC menunjukkan nilai rata-rata sebesar 3,6846. Hal ini berarti kinerja modal intelektual yang diukur berdasarkan value added yang diciptakan oleh value added capital employed (vaca), value added human capital (vahu), dan structural capital value added (stva) cukup kecil dalam standar devisiasi yaitu sebesar 1,61391 .

\section{Hasil Uji Asumsi Klasik}

\section{Uji Normalitas}

Uji normalitas bertujuan untuk mengetahui apakah distribusi sebuah data mengikuti atau mendekati distribusi normal. Apabila data tersebut telah berdistribusi normal, maka bisa dilanjutkan ke tahap berikutnya yaitu uji hipotesis. Untuk mengetahuinya, dilakukan metode uji normalitas yaitu dengan uji Kolmogorov-Smirnov. Dasar pengambilan keputusan pada uji KolmogorovSmirnov adalah berdasarkan nilai probabilitas. Jika nilai probabilitas lebih besar daripada 0.05 , maka dapat dikatakan bahwa data telah berdistribusi normal dan jika nilai probabilitas lebih kecil daripada

0.05, maka dapat dikatakan bahwa data tidak berdistribusi normal 
JUMANIS - BAJA VOL 4 NO 1 Prodi Kewirausahaan Februari 2022

ISSN : 2686-0554

ESSN : 2686-5939

DOI : $\mathbf{1 0 . 4 7 0 8 0}$

Tabel 2Hasil Uji Normalitas Data One-Sample Kolmogorov-Smirnov Test

\begin{tabular}{|ll|r|r|r|r|} 
& & \multicolumn{5}{|c|}{ Unstandardized Residual } \\
\cline { 3 - 6 } & & \multicolumn{1}{|c|}{ ROA } & \multicolumn{1}{c|}{ ATO } & \multicolumn{1}{c|}{ PBV } & \multicolumn{1}{c|}{ EG } \\
\cline { 3 - 7 } Normal & & 92 & 92 & 92 & \\
Parametersa,,b & Mean & .0000000 & .0000000 & .0000000 & .0000000 \\
& Std. & .84722223 & .00603922 & .96456333 & .6740335 \\
Most & & & & 4 \\
Extreme & Deviation & .099 & .139 & .146 & .197 \\
Differences & Absolute & .099 & .139 & .146 & .197 \\
Kolmogorov- & Positive & -.086 & -.102 & -.100 & -.134 \\
Asymp. Sig. (2-tailed) & .954 & 1.337 & 1.401 & 1.888 \\
& & .323 & .056 & .039 & .002
\end{tabular}

a. Test distribution is Normal.

b. Calculated from data.

Sumber: Data sekunder yang diolah dengan SPSS v 17 (2017)

Sesuai dengan uji Kolmogorov-Smirnov yang ditunjukkan oleh tabel Uji Normalitas maka diperoleh nilai probabilitas atau Asymp. Sig. (2-tailed) sebesar 0,$323 ; 0,056 ; 0,039 ; 0.002$ artinya lebih besar dari 0,05 , hal ini menunjukkan bahwa uji berdistribusi normal.

\section{Analisis Koefisien Determinan (R2)}

Koefisien determinasi (R Square) pada intinya mengukur seberapa jauh kemampuan model dalam menerangkan variasi variabel dependen. Koefisien determinasi digunakan untuk mengetahui keeratan hubungan antara variabel bebas djengan variabel terikat. Nilai koefisien determinasi 
adalah antara nol dan sampai dengan satu (Ghozali, 2013). Nilai koefisien determinasi dapat dilihat pada tabel berikut:

1. Pengaruh modal intelektual terhadap profitabilitas

Pengaruh modal intelektual terhadap profitabilitas yang di ukur ROA

\section{Tabel 3Koefisien Determinan (R2)}

Model Summary b

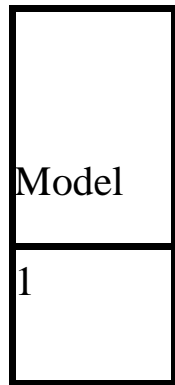

$$
\text { R } \mid \begin{array}{r}
\text { R Square } \\
.217
\end{array}
$$

Adjusted R

Square

.208

Std. Error of the Estimate

a. Predictors: (Constant), VAIC

b. Dependent Variable: ROA

Sumber : Data sekunder yang diolah oleh SPSS v 17 (2017)

Tabel 3 menunjukkan bahwa nilai $\mathrm{R}^{2}$ adalah sebesar 0,217 atau 21,7\%. Nilai adjusted $\mathrm{R}^{2}$ mengandung arti bahwa modal intelektual berpengaruh terhadap produktifitas yang diukur ROA sebesar $21,7 \%$ sedangkan 78,3\% dipengaruhi variabel lain.

\section{Pengaruh modal intelektual terhadap produktivitas}

Pengaruh modal intelektual terhadap produktivitas yang di ukur ATO

\section{Tabel 4}

\section{Koefisien Determinan (R2)}

$$
\text { Model Summaryb }
$$

\begin{tabular}{|c|c|c|c|c|}
\hline Model & $\mathrm{R}$ & R Square & Adjusted R Square & Std. Error of the Estimate \\
\hline 1 & .566 & .321 & .313 & .00607 \\
\hline
\end{tabular}

a. Predictors: (Constant), VAIC

b. Dependent variable : ATO

Sumber: Data sekunder yang diolah dengan SPSS v 17 (2017) 
JUMANIS - BAJA VOL 4 NO 1 Prodi Kewirausahaan Februari 2022

ISSN : 2686-0554

ESSN : 2686-5939

DOI : $\mathbf{1 0 . 4 7 0 8 0}$

Tabel 4 menunjukkan bahwa nilai $\mathrm{R}^{2}$ adalah sebesar 0.321 atau $32,1 \%$. Nilai adjusted $\mathrm{R}^{2}$ mengandung arti bahwa modal intelektual berpengaruh terhadap produktivitas yang diukur ATO sebesar 32,1\% sedangkan 67,6\% dipengaruhi variabel lain.

3. Pengaruh modal intelektual terhadap nilai pasar

Pengaruh modal intelektual terhadap nilai pasar yang di ukur PBV

Tabel 5

\section{Koefisien Determinan (R2)}

Model Summaryb

\begin{tabular}{|r|r|r|r|r|}
\hline Model & $\mathrm{R}$ & $\mathrm{R}$ Square & Adjusted R Square & Std. Error of the Estimate \\
.323 & .104 & .094 & 0.96991
\end{tabular}

a. Predictors: (Constant), VAIC

b. Dependent Variable: PBV

Sumber: Data sekunder yang diolah dengan SPSS v 17 (2017.

Tabel 5 menunjukkan bahwa nilai $\mathrm{R}^{2}$ adalah sebesar 0.104 atau $10,4 \%$. Nilai adjusted $\mathrm{R}^{2}$ mengandung arti bahwa modal intelektual berpengaruh terhadap nilai pasar yang diukur PBV sebesar 10,4\% sedangkan $89,6 \%$ dipengaruhi variabel lain.

4. Pengaruh modal intelektual terhadap pertumbuhan

Pengaruh modal intelektual terhadap pertumbuhan yang di ukur PBV

\section{Tabel 6Koefisien Determinan (R2)}

Model Summaryb

\begin{tabular}{|l|l|r|r|r|}
\hline Model & $\mathrm{R}$ & $\mathrm{R}$ Square & Adjusted R Square & Std. Error of the Estimate \\
\cline { 1 - 2 } & .035 & .001 & 010 & .67777 \\
\hline
\end{tabular}

a. Predictors: (Constant), VAIC

b. Dependent Variable: EG

Sumber: Data sekunder yang diolah dengan SPSS v 17 (2017) 
Tabel 6 menunjukkan bahwa nilai $\mathrm{R}^{2}$ adalah sebesar 0.001 atau $0.1 \%$. Nilai $\mathrm{R}^{2}$ mengandung arti bahwa modal intelektual berpengaruh terhadap nilai pasar yang diukur PBV sebesar 0,1\% sedangkan 99.9\% dipengaruhi variabel lain.

\section{Uji Parsial (Uji t)}

Uji parsial digunakan untuk mengetahui ada atau tidaknya pengaruh masing-masing variabel independen secara individual terhadap variabel dependen yang diuji pada tingkat signifikansi atau taraf nyata $\alpha$ sebesar 0,05 atau $5 \%$. Taraf nyata $\alpha$ diartikan sebagai peluang kita melakukan kesalahan untuk menyimpulkan bahwa H0 salah, padahal sebenarnya statement H0 yang benar. Dalam pengujian ini yang melihat pada nilai probabilitasnya, nilai probabilitas harus lebih kecil dari nilai $\alpha$ yang telah ditentukan. Hasil uji parsial dalam penelitian ini dapat dilihat pada tabel $7 \mathrm{di}$ bawah ini.

\section{Pengaruh modal intelektual terhadap profitabilitas}

\section{Tabel 7Uji t}

Coefficientsa

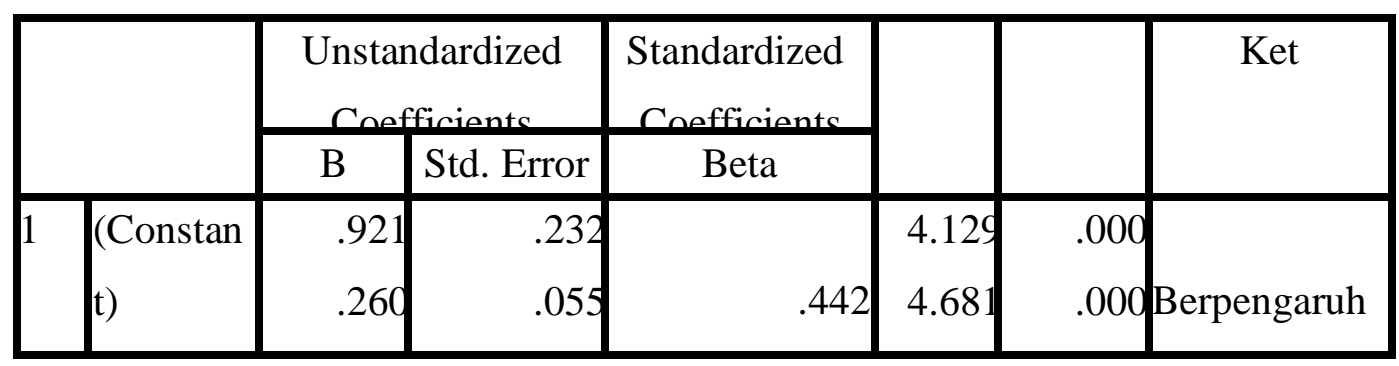

a. Dependent Variable: ROA

Sumber: Data sekunder yang diolah dengan SPSS v 17 (2017) 
Tabel 7 di atas menunjukkan hasil uji t antara variabel independen modal intelektual (VAIC) terhadap profitabilitas dengan sig 0,000. Karena $0,000<0,05$ bahwa modal intelektual (VAIC) berpengaruh positif terhadap profitabilitas maka hipotesis diterima.

\section{Pengaruh Modal Intelektual terhadap Produktivitas}

\section{Tabel 8 Uji t}

\section{Coefficientsa}

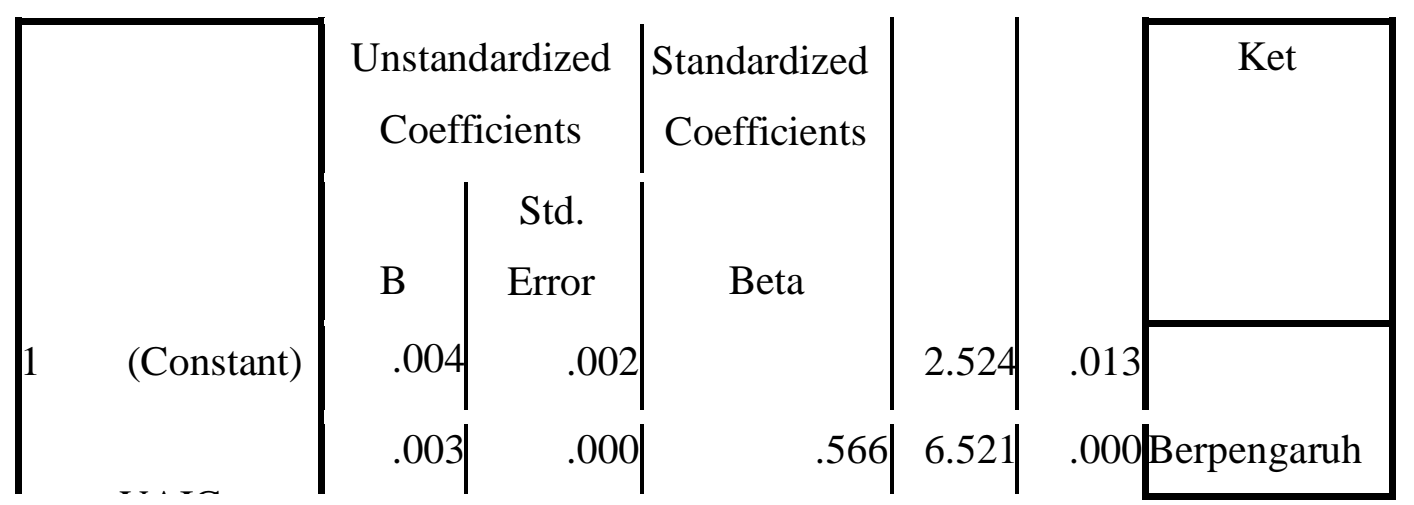

Dependent Variable: ATO

Sumber: Data sekunder yang diolah dengan SPSS v 17 (2017)

Tabel 8 di atas menunjukkan hasil uji t antara variabel independen modal intelektual (VAIC) terhadap asset turnover dengan sig 0,000. Karena $0,000<0,05$ bahwa modal intelektual (VAIC) berpengaruh positif terhadap asset turnover maka hipotesis diterima. 
JUMANIS - BAJA VOL 4 NO 1 Prodi Kewirausahaan Februari 2022

ISSN : 2686-0554

ESSN : 2686-5939

DOI : $\mathbf{1 0 . 4 7 0 8 0}$

\section{Pengaruh Modal Intelektual terhadap Nilai Pasar}

Tabel 9 Uji $t$

\section{Coefficientsa}

\begin{tabular}{|c|c|c|c|c|c|c|}
\hline & $\begin{array}{r}\text { Unstar } \\
\text { Coef }\end{array}$ & $\begin{array}{l}\text { ardized } \\
\text { cients }\end{array}$ & $\begin{array}{c}\text { Standardized } \\
\text { Coefficients }\end{array}$ & & & Ket \\
\hline Model & B & Error & Beta & $\mathrm{t}$ & Sig. & \\
\hline (Constant) & .822 & .264 & & 3.117 & .002 & \\
\hline VAIC & .160 & .067 & .244 & 2.386 & .019 & Berpengaruh \\
\hline
\end{tabular}

a. Dependent Variable: PBV

Sumber: Data sekunder yang diolah dengan SPSS v 17 (2017)

Tabel 9 di atas menunjukkan hasil uji t antara variabel independen modal intelektual

(VAIC) terhadap asset turnover dengan sig 0,000. Karena

$0,000<0,05$ bahwa modal intelektual (VAIC) berpengaruh positif terhadap asset turnover maka hipotesis diterima. 


\section{Pengaruh Modal Intelektual terhadap Pertumbuhan}

Tabel 10 Uji t

\section{Coefficients ${ }^{a}$}

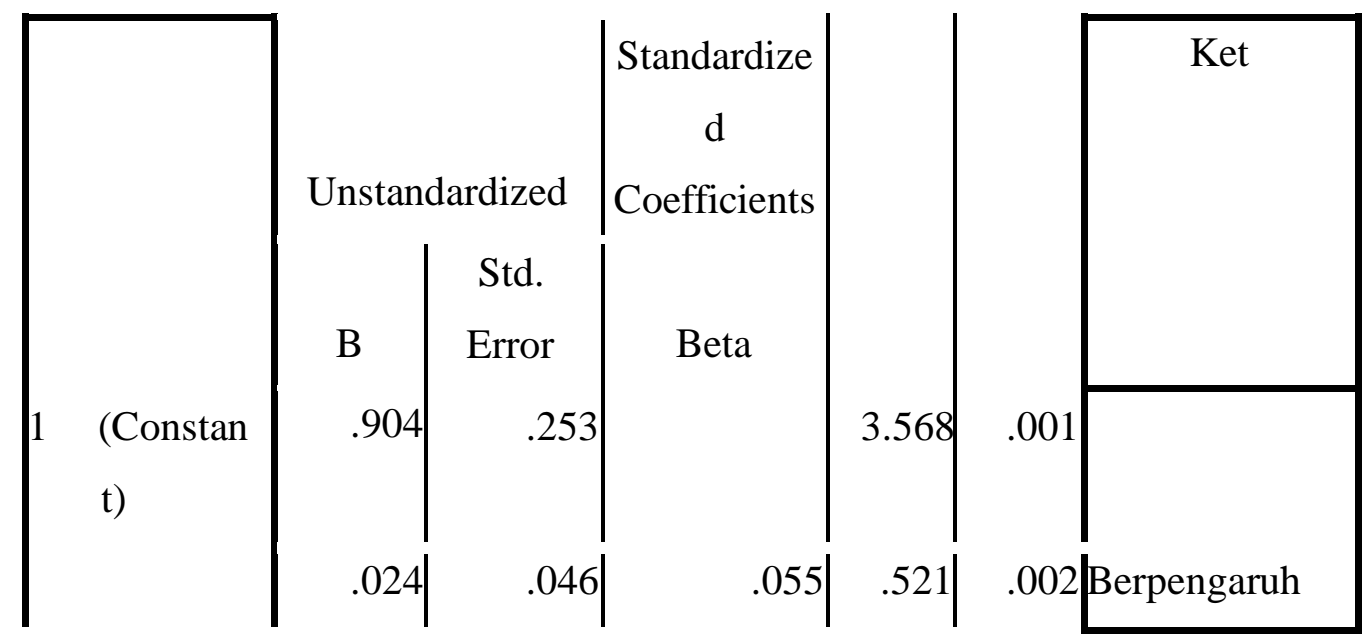

a. Dependent Variable: EG

Sumber: Data sekunder yang diolah dengan SPSS v 17 (2017)

Tabel 10 di atas menunjukkan hasil uji t antara variabel independen modal intelektual (VAIC) terhadap earning growth dengan sig 0,002. Karena 0,002 $<0,05$ bahwa modal intelektual (VAIC) berpengaruh positif terhadap price too book value (PBV) maka hipotesis diterima.

\section{E. KESIMPULAN DAN SARAN}

\section{Kesimpulan}

Berdasarkan hasil penelitian dan pembahasan, peneliti dapat meringkas hasil pada penelitian sebagai berikut :

1. Value Added Intellectual Capital (VAIC) berpengaruh positif terhadap profitabilitas (ROA) dan terbukti dapat meningkatkan profitabilitas perusahaan. Dengan demikian menunjukkan dengan penggunaan seluruh asset yang dimiliki perusahaan termasuk modal intelektual maka dapat menciptakan value added bagi perusahaan yang dapat mempengaruhi profitabilitas perusahaan. 
2. Value Added Intellectual Capital (VAIC) berpengaruh positif terhadap produktifitas (ATO). Hal ini berarti besar kecilnya modal intelektualtidak mempengaruhi tingkat perputaran aset pada perusahaan perbankan. Hal ini kemungkinan disebabkan karena modal intelektualwalaupun diperkenalkan sejak tahun 2000, namun dalam dunia praktek intellectual capital masih belum dikenal secara luas di Indonesia (Abidin, 2000).

3. Value Added Intellectual Capital (VAIC) berpengaruh positif terhadap nilai pasar yang diukur Price to Book Value (PBV) berpengaruh secara positif Perusahaan juga belum mengelola modal intelektual tersebut dengan baik dan benar untuk dijadikan sebagai penilaian atas kinerja perusahaan, serta sebagai informasi tambahan dalam pengambilan keputusan.

4. Value Added Intellectual Capital (VAIC) berpengaruh terhadap nilai pertumbuhan yang diukur Earning Growth (EG). Hal ini mengindiksikan bahwa semakin besar capital employed maka semakin besar investasi modal perusahaan dalam menciptakan nilai, sehingga perusahaan akan lebih mudah dalam meningkatkan pendapatannya

5. Modal intelektual mempunyai pengaruh yang sangat besar bagi perusahaan karena pada dasarnya modal intelektual adalah sumberdaya yang potensial untukmenentukan keunggulan kompetitif perusahaan tersebut karena merupakan faktor sumberdaya dan pengetahuan yang mendukung jalannya perusahaan.

\section{Saran}

Peneliti selanjutnya yang hendak mengkaji modal intelektual secara lebih mendalam dapat menambahkan objek penelitian pada jenis industriyang terdaftar di Bursa Efek Indonesia.Sebaiknya bagi penelitian yang akan datang, menggunakan obyek penelitian industri lain misalnya perusahaan manufaktur, dan industri lainnya yang terdaftar di BEI dengan periode yang lebih panjang, sehingga hasilnya dapat menggambarkan kondisi keseluruhan modal intelektualpada perusahaan di BEI. 


\section{DAFTAR PUSTAKA}

Alwin.A, Agustinus.S.A. 2017 Analisa Pengaruh Modal Intelektual Terhadap Profitabilitas, Produktifitas dan Penilaian Perusahaan (Studi Kasus Pada 35 Perusahaan LQ-45 di Bursa Efek Indonesia Periode 2012-2014)

Arifin, J., Suhadak, E. S. Astuti, Z. Arifin. 2014. The Influence of Corporate Governance, Intellectual Capital onFinancial Performance and Firm Value of Bank Sub-Sector Campanies Listed at Indonesia Stock Exchange in Period 2008-2012. European Journal of Business and Management Vol.6, No.26, 2014.

Arif. 2015. Pengaruh Struktur Modal, Return On Equity, Likuiditas, Dan Growth Opportunity Terhadap Nilai Perusahaan Pada Perusahaan Jasa Yang Terdaftar Di Bursa Efek Indonesia. Skripsi Sarjana (Tidak dipublikasikan), Yogyakarta: Fakultas Ekonomi Universitas Negeri Yogyakarta.

Azwar, A. Mufraini, Suhendra, S. Noor. 2011. Analisis Faktor Fundamental Terhadap Excess Return Saham Syariah Perusahaan Jakarta Islamic Index. Al-Iqtishad: Vol. III, No. 1, Januari 2011.

Arviansyah, Y. 2013. Pengaruh Struktur Modal, Kinerja Keuangan Perusahaan, Pertumbuhan Perusahaan Dan Ukuran Perusahaan Terhadap Nilai Perusahaan Pada Perusahaan Yang Terdaftar Di Jakarta Islamic Index (JII). Skripsi Sarjana (Tidak dipublikasikan), Jakarta: Fakultas Ekonomi dan Bisnis UIN Syarif Hidayatullah.

Ali, M dan M. Maryam. 2015. An Analysis of the Influence of Ownership Structure, Investment, Liquidity and Risk to Firm Value: Evidence from Indonesia. American Journal of Economics and Business Administration 2015, 7 (4): 166.176. Adenugba, A.A., A.A. Ige , O.R. Kesinro. 2016. Financial Leverage and Firms' Value: A Study of Selected Firms In Nigeria. European Journal of Research and Reflection in Management Sciences. Vol. 4 No. 1, 2016. 
JUMANIS - BAJA VOL 4 NO 1 Prodi Kewirausahaan Februari 2022

ISSN : 2686-0554

ESSN : 2686-5939

DOI : $\mathbf{1 0 . 4 7 0 8 0}$

Al-Nasser, N.M. 2014. The Impact of Financial Analysis in Maximizing the Firm's Value “A Case Study on the Jordanian Industrial Companies". International Journal of Managerial Studies and Research. Vol. 2, Issue 6, July 2014.

Aditya, M.A.E. 2015. Pengaruh Rasio Keuangan Terhadap Nilai Perusahaan Manufaktur yang Terdaftar di Bursa Efek Indonesia. Artikel Ilmiah, diajukan untuk memenuhi salah satu syarat penyelesaian program pendidikan sarjana jurusan Akuntansi. Sekolah Tinggi Ilmu Ekonomi PERBANAS, Surabaya.

Brigham dan Houtsan. 2001. Manajemen Keuangan. Erlangga.

Brigham, Eugene F. dan L.C. Gapenski. 1999. Intermediate Financial Management. Seaharbor Drive: The Dryden Press, USA.

Brealey, dkk. 2008. Dasar-dasar Manajemen Keuangan Perusahaan. Erlangga.

Bhunia, A., S.S. Mukhuti, S.G. Roy. 2011. Financial Performance Analysis-A Case Study. Current Research Journal of Social Sciences 3 (3): 269-275, 2011 ISSN: 2041-3246 () Maxwell Scientific Organization, 2011.

Gema Pramudita. 2012. Pengaruh Intellectual Capital terhadap Nilai Pasar dan Kinerja Keuangan Perusahaan Perbankan yang Terdaftar di Bursa Efek Indonesia (BEI) Tahun 2008-2010. Skripsi Universitas Diponegoro. Semarang.

Hidayat Halim. 2007. Peranan Strategis Modal Intellectual dalam Persaingan

Bisnis di Era Jasa Ekuitas. Vol. 5, No. 3. pp. 293 - 312.

Pulic, A. (2004). Intellectual capital - does it create or destroy value? Measuring BusinessExcellence, 8(1), 62-68.

Puntillo, P. (2009), "Intellectual capital and business performance. Evidence from Italian banking industry", Journal of Corporate Finance Research, Vol. 4 No. 12, pp. 97-115.

Randa, F., \& Solon, A. S. 2012. Pengaruh Modal Intelektual Terhadap Nilai Perusahaan. Jurnal Sistem Informasi Manajemen dan Akuntansi. 10(1): Hal 2447.

Rhonal Ramadhan. (2017), "Pengaruh Intelektual Capital Terhadap Kinerja Keuangan Pada Perusahaan Infrastruktur, Utilitas Dan Transportasi Jurnal Ilmu dan Riset Akuntansi Volume 6, Nomor 8, Agustus 2017 ISSN : 
JUMANIS - BAJA VOL 4 NO 1 Prodi Kewirausahaan Februari 2022

ISSN : 2686-0554

ESSN : 2686-5939

DOI : 10.47080

2460-0585

Santoso, S. 2012. Pengaruh Modal Intelektual dan Pengungkapannya Terhadap Kinerja Perusahaan. Jurnal Akuntansi dan Keuangan, Vol. 14, No. 1, hlm. 16-31

Septy Indra Santoso (2017), "Pengaruh Intellectual Capital Terhadap Pertumbuhan,

Nilai Pasar, Produktivitas Dan Profitabilitas Jurnal Ilmiah Akuntansi Peradaban,

Vol. III No. 2 Desember 2017

Solikhah, Badingatus, A. Rahman, dan Wahyu Merianto. 2010. Implikasi Intellectual Capital terhadap Financial Performance, Growth dan Market Value ; Studi Empiris dengan Pendekatan Simplistic Specification. Jurnal Simposium Nasional Akuntansi XIII. Purwokerto

Ulum, Ihyaul, dkk. 2008. "Intellectual Capital dan Kinerja Keuangan Perusahaan; Suatu Analisis dengan Pendekatan Partial Least Squares". SNA XI. Pontianak.Vishnu, S., \& Kumar Gupta, V. (2014). Intellectual capital and performance of pharmaceutical firms in India. Journal of Intellectual Capital, 15(1), 83-99.

Widyaningdyah, A. U., \& Aryani, Y. A. (2013). Intellectual Capital dan Keunggulan Kompetitif (Studi Empiris Perusahaan Manufaktur versi Jakarta Stock Industrial Classification-JASICA). Jurnal Akuntansi Dan Keuangan, 15(1), 1-14. 